\title{
Sensitivity of rat pancreatic A and B cells to somatostatin*
}

\author{
F.C.Schuit ${ }^{1}$, M.-P.Derde ${ }^{2}$ and D.G. Pipeleers ${ }^{3}$ \\ ${ }^{1}$ Department of Biochemistry, ${ }^{2}$ Department of Pharmaceutical Chemistry and \\ ${ }^{3}$ Department of Metabolism and Endocrinology, Vrije Universiteit Brussel, Belgium
}

\begin{abstract}
Summary. Islet A and B cells were purified from the rat pancreas and examined for their respective sensitivity to somatostatin. Both somatostatin-14 (S14) and -28 (S28) inhibited glucagon and insulin release through direct interactions with the corresponding cell types. A dose-dependent suppression of the secretory activities was paralleled by a reduction in cellular cyclic AMP formation with similar $\mathrm{ED}_{50}$ values for both actions. The somatostatin effects on pancreatic hormone release may thus be mediated via an inhibition of adenylate cyclase activity. In pancreatic A cells, S14 and S28 were equally potent inhibitors with $\mathrm{ED}_{50}$ values ranging from $2 \times 10^{-12}$ to $2 \times 10^{-11} \mathrm{~mol} / \mathrm{l}$. Pancreatic B cells exhibited a similar sensitivity to $\mathrm{S} 28$ as the A cells $\left(\mathrm{ED}_{50}\right.$ of 2 to $\left.5 \times 10^{-11} \mathrm{~mol} / \mathrm{l}\right)$, but not to $\mathrm{S} 14\left(\mathrm{ED}_{50}\right.$ of $\left.2 \times 10^{-9} \mathrm{~mol} / \mathrm{l}\right)$. Extrapolation of these in vitro sensitivities of islet $\mathrm{A}$ and $\mathrm{B}$ cells to the in vivo situation sug-
\end{abstract}

gests that both cell types can respond to circulating S28 levels and that A cells are sensitive to both locally and distally released S14. Islet B cells appear insensitive to the normal peripheral S14 levels but could respond to locally released somatostatin. The marked difference in the sensitivities of islet A and $B$ cells to $S 14$ suggests that these cell types are equipped with different somatostatin receptors. This notion was further supported by the cell-selective actions of the synthetic S14 analogues [D-Trp $\left.{ }^{8}, \mathrm{D}-\mathrm{Cys}^{14}\right] \mathrm{S} 14$ and $\operatorname{des} \mathrm{Asn}^{5}\left[\mathrm{D}-\mathrm{Trp}^{8}\right.$, DSer $\left.{ }^{13}\right] \mathrm{S} 14$.

Key words: Somatostatin, somatostatin analogues, insulin release, glucagon release, cyclic AMP, purified islet cells, pancreatic islets.
Somatostatin immunoreactive cells have been described in various sites of the body [1-6]; their hormonal products are synthesised as preprosomatostatin, a $12,000-14,000$ dalton prohormone $[7,8]$ and released as somatostatin-28 (S28) or somatostatin-14 (S14) [9-12]. The two latter peptides have been identified in the circulation and their administration in vivo and in vitro leads to the inhibition of a wide variety of physiologic processes [for review, see ref. 13]. In several cases, the specific action of each peptide could not be elucidated as it was difficult to distinguish direct from indirect interactions and to weigh the influence of the administered hormone versus that of the locally released one. In the endocrine pancreas, for example, addition of S14 or S28 leads to inhibition of insulin and glucagon release, with apparently differential effects of the two peptides [14-17]. It remains, however, unknown whether the two somatostatins act directly and independently of each other on both pancreatic $A$ and

\footnotetext{
* Part of this study has been presented at the 21st Annual Meeting of the European Association for the Study of Diabetes, Rome, Italy, 1986
}

B cells, whether the somatostatin-induced effects on one cell type influence the secretory function of the other, and whether locally released somatostatin - originating from the islet D cells - participates in the final response. One way to clarify somewhat this complex issue consists in examining the effects of S14, of S28 and of related peptides on purified pancreatic $A$ and B cells.

\section{Materials and methods}

\section{Materials}

Porcine glucagon was purchased from Novo Industries (Bagsvaerd, Denmark); S14 and its analogues, desAsn ${ }^{5}\left[\mathrm{D}-\operatorname{Trp}^{8}, \mathrm{D}-\mathrm{Ser}^{13}\right] \mathrm{S} 14$ and $\left[D-T_{r p}^{8}\right.$, D-Cys $\left.{ }^{14}\right] \mathrm{S} 14$ were obtained from UCB Bioproducts (Braine L'Alleud, Belgium). The purity of the S14 analogues was higher than $98 \%$ on TLC and HPLC (UCB product information). S28 came from Sigma (StLouis, Mo, USA). The lyophilised peptides were dissolved in $2 \mathrm{~mol} / 1$ acetic acid supplemented with $0.25 \%$ (wt/vol) bovine serum albumin (BSA; Boehringer-Mannheim, Mannheim, FRG), aliquoted and stored at $-80^{\circ} \mathrm{C}$. The phosphodiesterase inhibitor Ro 20-1724 was kindly provided by Hoffman-La Roche (Basel, Switzerland). 


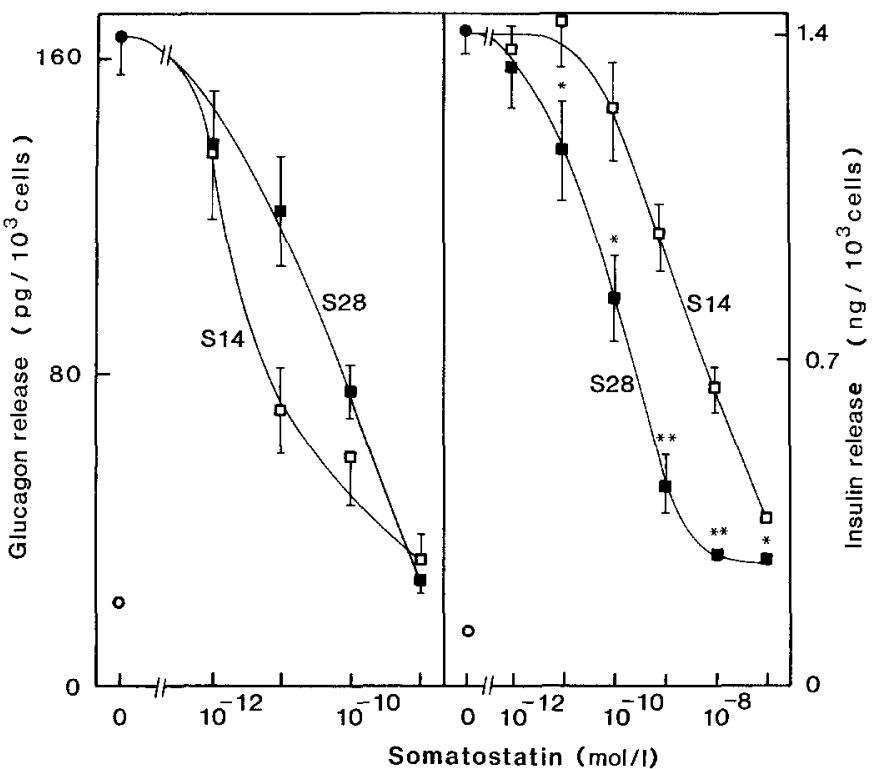

Fig. 1. Effect of somatostatin on glucagon and insulin release from purified A cells (left panel) and purified B cells (right panel). The cells were incubated for $15 \mathrm{~min}$ with or without somatostatin (S14: $\square$ S28: $\square$ ). For A cells, the medium was supplemented with alanine, arginine and glutamine ( $2 \mathrm{mmol} / 1$ each) with $1.4 \mathrm{mmol} / 1$ glucose and $10^{-6} \mathrm{~mol} / \mathrm{I}$ noradrenaline; for B cells, it contained $20 \mathrm{mmol} / 1$ glucose plus $10^{-8} \mathrm{~mol} / 1$ glucagon. The phosphodiesterase inhibitor Ro 20-1724 was added at min 10 (final concentration $100 \mu \mathrm{mol} / 1$ ). O basal control (EH with $1.4 \mathrm{mmol} / 1$ glucose); stimulus control (no somatostatin added). Data represent mean values \pm SEM of 5 experiments. The statistical significance of differences between effects of equimolar S14- and S28 concentrations was calculated by the paired Student's t-test. *: $p<0.05 ; * *: p<0.001$

\section{Purification of pancreatic $A$ and $B$ cells}

The techniques for the preparation of islet A and B cells have been described in full detail elsewhere [18-20]. Briefly, pancreatic islets were isolated from male adult Wistar rats using a modified collagenase technique [19]. The isolated islets were dissociated in calcium-free medium containing $1 \mathrm{mmol} / 1$ ethyleneglycol-bis-( $\beta$-aminoethyl ether) $\mathrm{N}, \mathrm{N}^{\prime}$-tetraacetic acid (EGTA), $25 \mu \mathrm{g} / \mathrm{ml}$ trypsin (BoehringerMannheim) and $2 \mu \mathrm{g} / \mathrm{ml} \mathrm{DN}$-ase (Boehringer) [18]. The dissociated cells were separated by autofluorescence-activated cell sorting into pure $A$ and pure $B$ cell preparations [19, 20]. The isolated cells were reaggregated for $2 \mathrm{~h}$ in a rotatory shaking incubator (Braun, Melsungen, FRG) and then statically cultured for $20 \mathrm{~h}$. The tissue culture medium was CMRL-1066 (GIBCO, Glasgow, UK) supplemented with $10 \%$ (vol/vol) heat-inactivated fetal calf serum (GIBCO), $2 \mathrm{mmol} / \mathrm{l} \mathrm{L-glu-}$ tamine, penicillin $(0.1 \mathrm{mg} / \mathrm{ml})$ and streptomycin $(0.1 \mathrm{mg} / \mathrm{ml})$.

\section{Incubations with S14, S28 and S14-analogues}

At the end of $20 \mathrm{~h}$ culture, the A and B cell aggregates were collected from the petri dishes and washed with Earle's HEPES medium (EH) containing $1.4 \mathrm{mmol} / 1$ glucose and $0.5 \% \mathrm{BSA}$. The composition of EH has been previously reported [19]. Cell viability as measured with neutral red [21], exceeded $90 \%$ in all experiments. Groups of $5 \times 10^{4}$ cells were distributed as $0.1 \mathrm{ml}$ samples over $5 \mathrm{ml}$ plastic tubes (Falcon, Oxnard, Calif., USA) containing $1.4 \mathrm{mI} \mathrm{EH}$. The cells were allowed to sediment for $20 \mathrm{~min}$, before $1 \mathrm{ml}$ of supernatant was carefully aspirated. The remaining $0.5 \mathrm{ml}$, containing the sedimented cell aggregates, was mixed with an additional volume of $0.5 \mathrm{ml}$ composed as to obtain the final experimental conditions for testing somatostatin (analogues). As it was the purpose to compare the inhibitory effects of the test substances, conditions were selected wherein the islet cells were stimulated through a synergistic interaction of nutrient- and adenylcyclase-dependent regulatory units [22-25]. Thus, pancreatic A cells were incubated at $1.4 \mathrm{mmol} / 1$ glucose supplemented with a mixture of amino acids (alanine, arginine and glutamine, $2 \mathrm{mmol} / 1$ each) and noradrenaline $\left(10^{-6} \mathrm{~mol} / \mathrm{l}\right)[22,24]$, whereas pancreatic $B$ cells were examined at $20 \mathrm{mmol} / 1$ glucose and $10^{-8} \mathrm{~mol} / 1$ glucagon [23-25]. The somatostatin (analogues) were administered at varying concentration, immediately before start of the $15 \mathrm{~min}$ incubation at $37^{\circ} \mathrm{C}$. At the end of incubation, the tubes were centrifuged $\left(1 \mathrm{~min}-250 \mathrm{~g}-4^{\circ} \mathrm{C}\right)$, the supernatant fractions aspirated and analysed for their insulin or glucagon content and the cell pellets resuspended in $0.5 \mathrm{ml} \mathrm{6 \%}$ trichloroacetic acid (TCA) in order to extract cellular cyclic AMP [25]. The phosphodiesterase inhibitor Ro 20-1724 was added during the last $5 \mathrm{~min}$ of incubation in order to create the conditions for measuring the rate of cyclic AMP formation in parallel to the insulin or glucagon release.

\section{Insulin, glucagon and cyclic AMP assays}

Cyclic AMP was measured as described previously [25]. The TCA supernatant fraction was extracted four times with $4 \mathrm{ml}$ water-saturated diethylether, lyophilised, and redissolved in $0.05 \mathrm{~mol} / 1$ sodium acetate buffer ( $\mathrm{pH}$ 6). The cyclic AMP content of the samples was measured after acetylation with a commercially available $\left[{ }^{125} \mathrm{I}\right]$-cyclic AMP radio immuno assay kit (Amersham, Bucks, UK) and is expressed as femtomole per $10^{3}$ cells ( $\mathrm{fmol} / 10^{3}$ cells). Insulin and glucagon were measured by radio immuno assay using HPLC-purified $\left[{ }^{125} \mathrm{I}\right]$-insulin and $\left[{ }^{125} \mathrm{I}\right]$-glucagon tracers [26].

\section{Statistical analysis}

Data represent mean values \pm SEM of at least four independent experiments. The statistical significance of differences between control and experimental conditions was calculated with two-tailed Student's t-tests. The acceptance level of significance $(p<0.05)$ was corrected with the Bonferroni method in case of multiple comparisons [27]. $\mathrm{ED}_{50}$ values were calculated with a logit approach based on normal distribution and least square regression analysis [28] and compared with a modified t-test [29].

\section{Results}

\section{Effect of S14 and S28 on hormone release from pancreatic $A$ and $B$ cells}

Both S14 and S28 exerted a potent inhibition on glucagon release induced by a mixture of amino acids and noradrenaline (Fig.1, left panel). Their effect was already observed at $10^{-11} \mathrm{~mol} / 1(p<0.05)$; complete suppression was obtained at $10^{-9} \mathrm{~mol} / 1$.

The two peptides were also inhibitory to insulin release induced by a mixture of glucose and glucagon (Fig.1, right panel). This effect became statistically significant at $10^{-11} \mathrm{~mol} / 1$ for $\mathrm{S} 28(p<0.05)$ and at $10^{-9}$ $\mathrm{mol} / 1$ for $\mathrm{S} 14(p<0.001)$; maximal inhibition required concentrations of $10^{-8} \mathrm{~mol} / 1$ for $\mathrm{S} 28$ and higher than $10^{-7} \mathrm{~mol} / 1$ for $\mathrm{S} 14$.

Table 1 summarises the concentrations needed to obtain half-maximal inhibition ( $E D_{50}$ values) for these 
Table 1. $E D_{50}$ values of somatostatin-induced inhibition of hormone release and $\mathrm{CAMP}$ production

\begin{tabular}{|c|c|c|c|c|c|c|c|}
\hline & & $\mathrm{ED}_{50}$ valu & $1 \mathrm{ol} / 1)$ & & & & \\
\hline & & Inhibition & ormone release & & Inhibition & MP production & \\
\hline S14 & A cells & $10^{-11}$ & {$\left[4 \times 10^{-12} ; 3 \times 10^{-11}\right]$} & $p<0.001$ & $2 \times 10^{-12}$ & {$\left[10^{-12} ; 4 \times 10^{-12}\right]$} & $p<0.001$ \\
\hline S14 & $\mathrm{B}$ cells & $2 \times 10^{-9}$ & {$\left[10^{-9} ; 4 \times 10^{-9}\right]$} & .001 & $2 \times 10^{-9}$ & {$\left[9 \times 10^{-10} ; 4 \times 10^{-9}\right]$} & $p<0.00 t$ \\
\hline $\mathrm{S} 28$ & A cells & $2 \times 10^{-11}$ & {$\left[9 \times 10^{-12} ; 5 \times 10^{-11}\right]^{\mathrm{a}}$} & NS & $8 \times 10^{-12}$ & {$\left[4 \times 10^{-12} ; 10^{-11}\right]^{a}$} & NS \\
\hline $\mathrm{S} 28$ & $\mathrm{~B}$ cells & $5 \times 10^{-11}$ & {$\left[3 \times 10^{-11} ; 10^{-10}\right]^{b}$} & No & $2 \times 10^{-11}$ & {$\left[10^{-11} ; 4 \times 10^{-11}\right]^{\mathrm{b}}$} & ND \\
\hline
\end{tabular}

Data represent mean values with corresponding $95 \%$ confidence intervals and were obtained after linear transformation of the sigmoid curves of Figure 3 using a logit approach based on normal distribution and least square regression analysis [28]. Significance of differences between estimated $\mathrm{ED}_{50}$ values was assessed with a modified t-test [29]. A cells versus $\mathrm{B}$ cells: $\mathrm{NS}=$ not significant at $p<0.05 \cdot \mathrm{S} 14$ versus $\mathrm{S} 28:^{\mathrm{a}}=$ not significant at $p<0.05 ;{ }^{\mathrm{b}}=$ significant at $p<0.001$

effects. For pancreatic A cells, the $\mathrm{ED}_{50}$ values of $\mathrm{S} 14$ $\left(10^{-11} \mathrm{~mol} / \mathrm{l}\right)$ and $\mathrm{S} 28\left(2 \times 10^{-11} \mathrm{~mol} / \mathrm{l}\right)$ were not significantly different. With pancreatic $B$ cells however, the $\mathrm{ED}_{50}$ value of $\mathrm{S} 14\left(2 \times 10^{-9} \mathrm{~mol} / \mathrm{l}\right)$ was 40 -fold higher than that of $\mathrm{S} 28(p<0.001)$.

\section{Effect of S14 and S28 on cyclic AMP production in pancreatic $A$ and $B$ cells}

Pancreatic A cells were suppressed in their noradrenaline-induced cyclic AMP production when exposed to S14 or S28 (Fig. 2, left panel). Inhibition occurred at $10^{-11} \mathrm{~mol} / 1(p<0.05)$ and was complete at $10^{-10} \mathrm{~mol} / 1$. At $10^{-11} \mathrm{~mol} / 1, \mathrm{~S} 14$ was a more potent suppressor than $\mathrm{S} 28(p<0.01)$.

S14 and S28 also suppressed cyclic AMP production in pancreatic B cells stimulated by glucagon and glucose (Fig. 2, right panel). Significant inhibition was induced at $10^{-11} \mathrm{~mol} / 1 \mathrm{~S} 28(p<0.05)$ but required 1000 -fold higher concentrations of S14. Complete suppression was achieved by $10^{-9} \mathrm{~mol} / 1 \mathrm{~S} 28$ and $10^{-7}$ $\mathrm{mol} / 1 \mathrm{~S} 14$. In the intermediate concentration range, $\mathrm{S} 28$ appeared a more powerful inhibitor than S14 (Fig. 2).

The $\mathrm{ED}_{50}$ values for the somatostatin inhibition of cAMP production in A cells were $2 \times 10^{-12} \mathrm{~mol} / 1$ with S14 and $8 \times 10^{-12} \mathrm{~mol} / 1$ with S28 $(p>0.05$; Table 1$)$. In pancreatic B cells, the $\mathrm{ED}_{50}$ value of S14 $\left(2 \times 10^{-9}\right.$ $\mathrm{mol} / \mathrm{l})$ was 100 -fold higher than that of $\mathrm{S} 28(p<0.001$; Table 1). The $\mathrm{ED}_{50}$ values for somatostatin-induced inhibition of hormone release were not significantly different from those for the inhibition of cAMP production in the corresponding conditions (Table 1).

\section{Sensitivity of pancreatic $A$ and $B$ cells for $S 14$ and $S 28$}

In order to compare the sensitivities of pancreatic $\mathrm{A}$ and $B$ cells for $\mathrm{S} 14$ and $\mathrm{S} 28$, the respective effects of the peptides were expressed as a percent of the total suppressible activity, be it hormone release (Fig. 3 - left panels) or cyclic AMP production (Fig. 3 - right panels). For somatostatin-14, it was noted that the process of hormone release and that of cAMP production could be suppressed in the picomolar range in the case of A cells

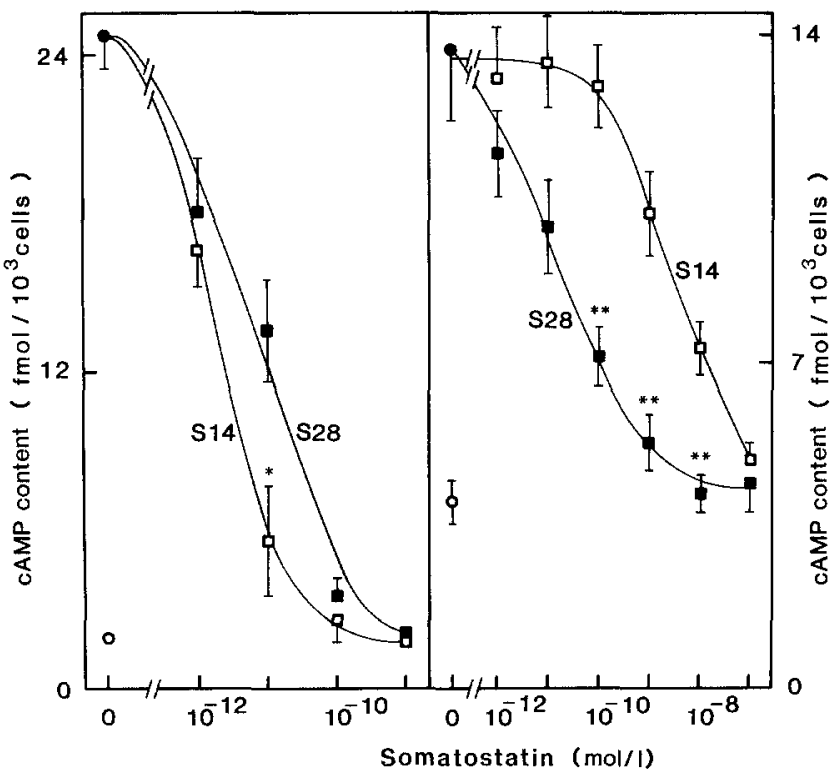

Fig. 2. Effect of S14 and S28 on cyclic AMP levels in purified A and $B$ cells. A cells (left panel) and B cells (right panel) were incubated with different S14 (ㅁ) or S28 (ש) concentrations (see legend of Fig.1), and cyclic AMP measured in the cell pellets. $O$ basal control (EH with $1.4 \mathrm{mmol} / 1$ glucose); stimulus control (no somatostatin added). Data represent mean values \pm SEM of 5 experiments. The statistical significance of differences between effects of equimolar S14 and S28 concentrations was calculated by the paired Student's t-test. *: $p<0.05 ; * *: p<0.001$

but only in the nanomolar range in the case of pancreatic B cells (Fig. 3, top panels). On the contrary, a similar sensitivity of A and B cells for somatostatin- 28 was noted as the dose-response curves for this peptide could be superimposed (Fig. 3 lower panels). The $E_{50}$ values for the inhibitory effects of $\mathrm{S} 14$ on hormone release and cAMP production were 200 to 1000 -fold higher in pancreatic B cells than in pancreatic A cells $(p<0.001-$ Table 1). On the other hand, no significant difference was found in the $\mathrm{ED}_{50}$ values of the $\mathrm{S} 28$ effects on both cell types.

\section{Effect of somatostatin-14 analogues}

In view of the observed difference in sensitivity of pancreatic A and B cells to somatostatin-14, we examined the cell-selectivity of two synthetic somatostatin-14 


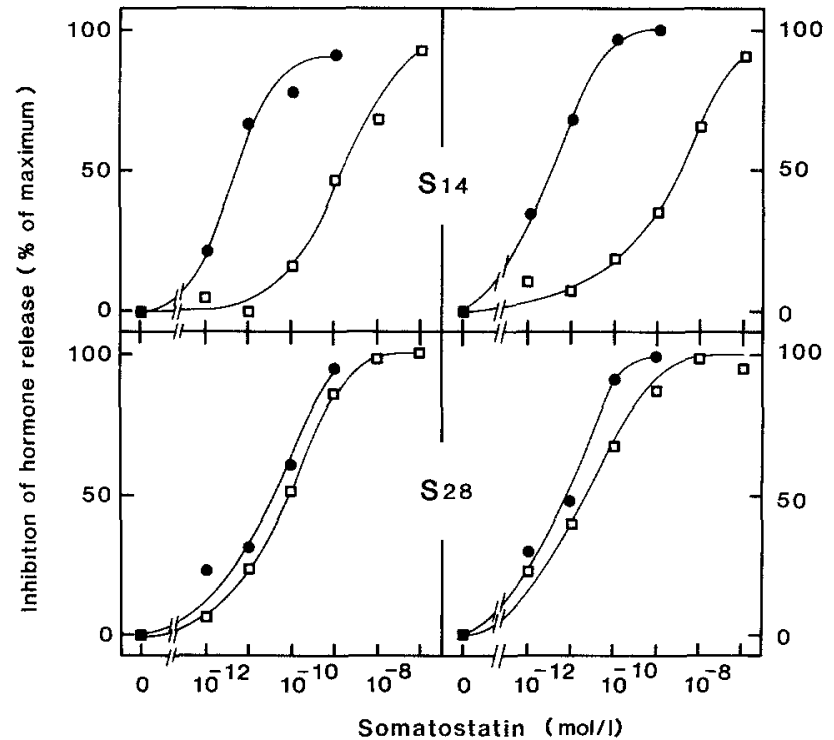

Fig. 3. Comparison of the sensitivity of purified A and B cells to somatostatin inhibition. Data are derived from the experiments shown in Figures 1 and 2. Effects of S14 (upper panels) and S28 (lower panels) on glucagon (O) and insulin ( $\square$ ) release (left panels) and on cyclic AMP production in A (O) and B cells $(\square)$ (right panels). Data are expressed as $\%$ of maximal inhibition, which was observed at $10^{-7}$ $\mathrm{mol} / 1$ somatostatin for B cells and $10^{-9} \mathrm{~mol} / 1$ for $A$ cells

analogues, namely $\left[\mathrm{D}-\operatorname{Trp}^{8}\right.$, D-Cys $\left.{ }^{14}\right] \mathrm{S} 14$ (D-Cys in Fig. 4) and desAsn ${ }^{5}\left[\mathrm{D}-\operatorname{Trp}^{8}\right.$, D-Ser $\left.{ }^{13}\right] \mathrm{S} 14$ (D-Ser in Fig. 4).

At a concentration of $10^{-10} \mathrm{~mol} / 1$, [D-Trp ${ }^{8}$, DCys ${ }^{14} \mathrm{~S} 14$ exerted effects that were more pronounced than those observed with S14: the functions of pancreatic $A$ cells were almost completely suppressed, whereas no significant inhibition was measured with pancreatic B cells (Fig. 4). When desAsn ${ }^{5}\left[\mathrm{D}-\mathrm{Trp}^{8}{ }^{8}, \mathrm{D}-\mathrm{Ser}^{13}\right] \mathrm{S} 14$ was tested - even at a 10-fold higher concentration - it did not suppress glucagon release or cyclic AMP production in the A cell preparations (Fig. 4), but reduced insulin release and cAMP production in pancreatic B cells $(p<0.01)$ similar to equimolar S14 concentrations (Fig. 4).

\section{Discussion}

The availability of purified pancreatic A and B cells permits to investigate in further detail the inhibitory action of somatostatin upon the endocrine pancreas [22, $23,25]$.

Our results confirm that somatostatin-14 can inhibit glucagon and insulin release via direct interactions with, respectively, A and B cells [22, 23] and extend this property to somatostatin-28. The inhibitory effects of S14 and S28 on hormone release were dose-dependent and closely parallelled by similar reductions in cyclic AMP formation as indicated by the respective $\mathrm{ED}_{50}$ values. A reduced adenylcyclase activity may thus mediate - at least in part - the inhibitory effect of soma-

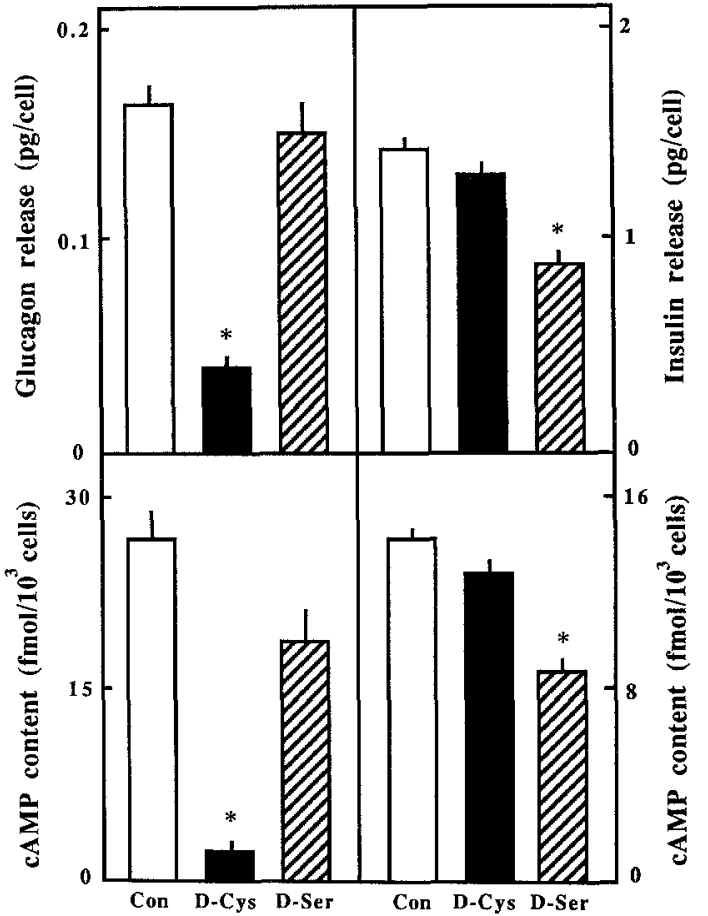

Fig.4. Effect of S14 analogues on hormone release (upper panels) and cyclic AMP content (lower panels) from A cells (left panels) and $B$ cells (right panels). The cells were incubated for $15 \mathrm{~min}$ with either $\left[\mathrm{D}-\operatorname{Trp}^{8}, \mathrm{D}-\mathrm{Cys}^{14}\right] \mathrm{S} 14$ (D-Cys; $10^{-10} \mathrm{~mol} / \mathrm{l}$ ) or desAsn ${ }^{5}\left[\mathrm{D}-\mathrm{Trp}^{8}{ }^{8} \mathrm{D}\right.$ Ser ${ }^{13}$ JS14 (D-Ser; $10^{-9} \mathrm{~mol} / 1$ ); no somatostatin was added in the control condition (Con). Data represent mean values \pm SEM of 4 experiments. The statistical significance of differences between conditions with somatostatin analogues and control was calculated with the unpaired Student's t-test and was corrected with the Bonferroni method for multiple comparisons [27]. ${ }^{*}: p<0.01$ versus control

tostatin on pancreatic hormone release [22, 25]. Somatostatin also suppresses cyclic AMP production in other cell types [30-32]. Its ability to inhibit glucagon or insulin release may thus depend on the degree to which these processes are activated by the adenylcyclase unit at the time of exposure. The possibility nevertheless remains that somatostatin is also capable of influencing the hormone release process via additional, cyclic AMP-independent, routes [33, 34].

The pancreatic A cells were inhibited by low somatostatin concentrations $\left(\mathrm{ED}_{50}\right.$ values between $2 \times 10^{-12}$ $\mathrm{mol} / 1$ and $\left.2 \times 10^{-11} \mathrm{~mol} / \mathrm{l}\right)$. These levels can be considered as physiologic even if pancreatic somatostatin has no direct access to the neighbouring A cells. Plasma somatostatin levels vary between $10^{-12} \mathrm{~mol} / 1$ and $5 \times 10^{-11} \mathrm{~mol} / \mathrm{l}[35]$ and may thus influence the rate of glucagon release in vivo. Since S14 seems - in this concentration range - a more potent inhibitor than $\mathrm{S} 28$, it is conceivable that the relative proportions of both forms will further modulate the degree of inhibition.

Pancreatic B cells were only suppressed by S14 concentrations of $10^{-9} \mathrm{~mol} / \mathrm{l}$ or higher. This relatively low sensitivity to the exogenous hormone should not be attributed to the presence of endogenously released S14 as the purified $\mathrm{B}$ cell preparation contains less than 
3 percent D-cells [19] and as the endogenous somatostatin levels measured in the controls were lower than $10^{-11} \mathrm{~mol} / 1$ [22]. It is also unlikely that it is caused by damage during tissue dissociation since pancreatic A cells - which were exposed to the same procedure as the B cells - exhibited an exquisite responsiveness to S14. Moreover, the isolated B cells have been previously shown to exhibit high affinity binding sites for other peptides [26, 36], and were found, in this paper, to be sensitive to concentrations of S28 in the picomolar range, a sensitivity which is similar to that previously noted in intact pancreata $[16,17]$. When extrapolated to the in vivo situation, these data suggest that the regulation of insulin release by somatostatin-14 is only conceivable if pancreatic somatostatin reaches the islet $B$ cells before it is diluted in the general circulation. It is still unclear whether such direct access exists via the intercellular space or via the local circulation. According to Bonner-Weir and Orci [37] and Kawai et al. [38], the intra-islet vascularisation does not permit an influence via the local circulation. The fact that purified $\mathrm{B}$ cells were nearly 50 -fold more sensitive to $\mathrm{S} 28$ (Table 1 ), suggests a regulatory role for circulating $\mathrm{S} 28$, which mainly originates from the gastrointestinal tract.

A comparison of the $\mathrm{ED}_{50}$ values indicates that $\mathrm{S} 14$ is approximately 500 -fold more potent in pancreatic A cells than in B cells. This difference in biological activity may result from the existence of two different somatostatin receptors, i. e. high affinity S14 receptors on A cells and low affinity binding sites for S14 on B cells. The results obtained with $\mathrm{S} 14$ analogues support this view, as one analogue acted preferentially on A cells reproducing the marked suppressive effects of S14 whereas the other remained without effect on A cells but induced a modest inhibition in B cells. The in vitro findings with these drugs are in good agreement with previous in vivo observations [39-41]. The physiologic meaning of the different sensitivity of pancreatic $A$ and $B$ cells to S14 is still unclear. It may represent another example of the divergent regulation which can be expected for the release of counteracting hormones [24]. The respective hormone responses thus become dependent on the origin and the extent of the increased S14 levels. Locally, this different sensitivity to S14 may be part of a functional integration of the various islet cell types. On the other hand, the $\mathrm{ED}_{50}$ values for the suppressive effects of S28 indicate that both cell types are highly and equally sensitive to this peptide. Pancreatic A and B cells seem therefore to be equipped with high affinity $\$ 28$ receptors.

The similarity in S28 sensitivity and the difference in S14 sensitivity suggest that the putative somatostatin receptor on A cells is to be distinguished from that on B cells. Cell-selective binding of S14 and S28 has also been suggested on the basis of autoradiographic studies in unpurified rat islet cell monolayers [42]. Binding studies with intact purified A and B cells are of course necessary to further document the existence of different somatostatin receptors on both cell types. These experiments will also tell whether the high affinity 228 receptors on B cells provide low affinity binding sites for S14.

Acknowledgments. The authors thank R. De Proft and G.Schoonjans for expert technical assistance, and N.Van Slycke for careful secretarial work. This study was supported by grants from the Belgian Ministry of Scientific Policy (86/91-102) and from the Fund for Medical Scientific Research (FGWO 3.0075.88). F.C.S. was a research assistant at the National Fund for Scientific Research (NFWO) Belgium.

\section{References}

1. Brazeau P, Vale W, Burgus R, Ling N, Butcher M, Rivier J, Guillemin R (1973) Hypothalamic polypeptide that inhibits the secretion of immunoreactive pituitary growth hormone. Science 179: $77-79$

2. Luft R, Efendic S, Hökfelt T, Johansson O, Arimura A (1974) Immunohistochemical evidence for the localization of somatostatinlike immunoreactivity in a cell population of the pancreatic islets. Med Biol 52: 428-430

3. Dubois MP (1975) Immunoreactive somatostatin is present in discrete cells of the endocrine pancreas. Proc Natl Acad Sci USA 72: $1340-1343$

4. Polak JM, Grimelius L, Pearse AGE, Bloom SR, Arimura A (1975) Growth-hormone release-inhibiting hormone in gastrointestinal and pancreatic D cells. Lancet II: $1220-1222$

5. Arimura A, Sato H, Dupont A, Nishi N, Schally AV (1975) Somatostatin: abundance of immunoreactive hormone in rat stomach and pancreas. Science 189: 1007-1009

6. Hökfelt T, Efendic S, Johansson O, Luft R, Arimura A (1974) Immunohistochemical localization of somatostatin (growth hormone releasing-inhibiting factor) in the guinea-pig brain. Brain Res 80 ; $165-169$

7. Hobart P, Crawford R, Shen LP, Pictet R, Rutter WJ (1980) Cloning and sequence analysis of cDNAs encoding two distinct somatostatin precursors found in the endocrine pancreas of anglerfish. Nature 288: 137-141

8. Goodman RH, Aron DC, Roos BA (1983) Rat pre-prosomatostatin: structure and processing by microsomal membranes. J Biol Chem 258: 5570-5573

9. Pradayrol L, Jörnvall H, Mutt V, Ribet A (1980) N-terminally extended somatostatin: the primary structure of somatostatin-28. Febs Lett 109: 55-58

10. Benoit R, Böhlen P, Brazeau P, Ling N, Guillemin R (1980) Isolation and characterization of rat pancreatic somatostatin. Endocrinology 107: 2127- 2129

11. Patel YC, Wheatley T, Ning C (1981) Multiple forms of immunoreactive somatostatin: comparison of distribution in neural and nonneural tissues and portal plasma of the rat. Endocrinology 109: 1943-1949

12. Gluschankof $P$, Morel A, Gomez S, Nicolas $P$, Fahy C, Cohen $P$ (1984) Enzymes processing somatostatin precursors: an Arg-Lys esteropeptidase from the rat brain cortex converting somatostatin28 into somatostatin-14. Proc Natl Acad Sci USA 81: 6662-6666

13. Reichlin S (1983) Somatostatin. N Engl J Med 309: 1495-1501 (part I) and 1556-1563 (part II)

14. Alberti KGMM, Christensen SE; Iversen J, Seyer-Hansen K, Christensen NJ, Prange Hansen AA, Lundbaek K, Ørskov H (1973) Inhibition of insulin secretion by somatostatin. Lancet II: 1299-1301

15. Koerker DJ, Ruch W, Chideckel E, Palmer J, Goodner CJ, Ensinck J, Gale CC (1974) Somatostatin: hypothalamic inhibitor of the endocrine pancreas. Science 184: 482-484

16. Mandarino L, Stenner D, Blanchard W, Nissen S, Gerich J, Ling N, Brazeau P, Bohlen P, Esch F, Guillemin R (1981) Selective effects of somatostatin-14, -25 and -28 on in vitro insulin and glucagon secretion. Nature 291: 76-77 
17. Brown M, Rivier J, Vale W (1981) Somatostatin 28: selective action on the pancreatic $\beta$-cell and brain. Endocrinology 108: 2391-2393

18. Pipeleers DG, Pipeleers-Marichal MA (1981) A method for the purification of single A, B and D cells and for the isolation of coupled cells from isolated rat islets. Diabetologia 20:654-663

19. Pipeleers DG, In't Veld PA, Van De Winkel M, Maes E, Schuit FC, Gepts W (1985) A new in vitro model for the study of pancreatic A and B cells. Endocrinology 117: 806-816

20. Van de Winkel M, Maes E, Pipeleers D (1982) Islet cell analysis and purification by light scatter and autofluorescence. Biochem Biophys Res Commun 107: 525-532

21. Pipeleers D, Van De Winkel M (1986) Pancreatic B cells possess defense mechanisms against cell-specific toxicity. Proc Natl Acad Sci USA 83: 5267-5271

22. Pipeleers DG, Schuit FC, Van Schravendijk CFH, Van De Winkel M (1985) Interplay of nutrients and hormones in the regulation of glucagon release. Endocrinology 117: 817-823

23. Pipeleers DG, Schuit FC, In't Veld PA, Maes E, HooghePeters EL, Van De Winkel M, Gepts W (1985) Interplay of nutrients and hormones in the regulation of insulin release. Endocrinology 117: 824-833

24. Schuit FC, Pipeleers DG (1986) Differences in adrenergic recognition by pancreatic A and B cells. Science 232: 875-877

25. Schuit FC, Pipeleers DG (1985) Regulation of adenosine $3^{\prime}, 5^{\prime}$ monophosphate levels in the pancreatic B cell. Endocrinology 117: $834-840$

26. van Schravendijk CFH, Foriers A, Hooghe-Peters EL, Rogiers V, De Meyts P, Sodoyez JC, Pipeleers DG (1985) Pancreatic hormone receptors on islet cells. Endocrinology 117: 841-848

27. Hochberg Y, Tamhane AC (1987) Multiple comparison procedures. Wiley, New York, p 30

28. Govindarajulu Z (1988) Statistical techniques in bioassay. Karger, Basel, pp 28-34

29. Commisariat à l'Energie Atomique (1978) Statistique Appliquée à l'Exploitation des Mesures. Masson, Paris, p 371

30. Heisler S, Reisine TD, Hook VYH, Axelrod J (1982) Somatostatin inhibits multireceptor stimulation of cyclic AMP formation and corticotropin secretion in mouse pituitary tumor cells. Proc Natl Acad Sci USA 79: 6502-6506

31. Jakobs KH, Schultz G (1983) Occurrence of a hormone-sensitive inhibitory coupling component of the adenylate cyclase in S49 lymphoma cyc-variants. Proc Natl Acad Sci USA 80: 3899-3902
32. Koch BD, Schonbrunn A (1984) The somatostatin receptor is directly coupled adenylate cyclase in $\mathrm{GH}_{4} \mathrm{C}_{1}$ pituitary cell membranes. Endocrinology 114: 1784-1790

33. Reisine T (1985) Multiple mechanisms of somatostatin inhibition of adrenocorticotropin release from mouse anterior pituitary tumor cells. Endocrinology 116: 2259-2266

34. Koch BD, Dorflinger LJ, Schonbrunn A (1985) Pertussis toxin blocks both cyclic AMP-mediated and cyclic AMP-independent actions of somatostatin. J Biol Chem 260: 13138-13145

35. Mackes K, Itoh M, Greene K, Gerich J (1981) Radioimmunoassay of human plasma somatostatin. Diabetes 30:728-734

36. van Schravendijk CFH, Foriers A, Van den Brande JL, Pipeleers DG (1987) Evidence for the presence of type I insulin-like growth factor receptors on rat pancreatic A and B cells. Endocrinology 121: 1784-1788

37. Bonner-Weir S, Orci L (1982) New perspectives on the microvasculature of the islets of Langerhans in the rat. Diabetes 31 : 883-889

38. Kawai K, Ipp E, Orci L, Perrelet, Unger RH (1982) Circulating somatostatin acts on the islets of Langerhans by way of a somatostatin-poor compartment. Science 218: 477-478

39. Brown M, Rivier J, Vale W (1976) Somatostatin analogs with selected biological activities. Science 196: 1467-1469

40. Vale W, Rivier J, Ling N, Brown M (1978) Biologic and immunologic activities and applications of somatostatin analogs. Metabolism 27: 1391-1401

41. Taborsky GJ Jr, Smith PH, Porte D Jr (1979) Differential effects of somatostatin analogues on $\alpha$ - and $\beta$-cells of the pancreas. Am J Physiol 236: E123-E128

42. Amherdt M, Patel YC, Orci L (1987) Selective binding of somatostatin-14 and somatostatin-28 to islet cells revealed by quantitative electron microscopic autoradiography. J Clin Invest 80: $1455-1458$

Received: 2 September 1988

and in revised form: 20 January 1989

D. G. Pipeleers

Department of Metabolism and Endocrinology

Vrije Universiteit Brussel

Laarbeeklaan 103

B-1090 Brussel

Belgium 